\title{
ЭКОЛОГИЯ ЧЕЛОВЕКА И ЭКОЛОГИЧЕСКОЕ ОБРАЗОВАНИЕ
}

\author{
МАРГАРИТА СМИРНОВА \\ Виестура просп. 43 - 66, Рига, Латвил, LV - 1005 \\ T.: 7395759
}

«Нас вылечат, прооперируют, пропишут нам лекарства и процедуры...», а сами мы, часто повинуясь, пассивно выполняем то, что назначено врачом. «Не занимайтесь самолечением!» - строго диктует традиционная медицина. Примерно так рассуждали наши предки, так же в основной массе относимся мы к своему здоровью, вспоминая о здоровье и здоровом духе тогда, когда что-то назойливо беспокоит. Молодёжьь пренебрегает даже серьёзными симптомами, а иногда и сами вредят своему здоровью. Хотя, здоровьпй от природы молодой человек, как правило, сам справляется с недомоганием. Статистика же неумолима: всё меньше в нашем мире рождается здоровых детей! И здесь повинна не только окружающая среда (кстати вся: живая и неживая), но также и мысли человека, его духовность, стремления и его недостаточное пувство уверенности в себе. С возрастом в этом плане мы несколько умнеем, начхнаем разбираться в заболеваниях, одним врачам доверяем, другим - нет. Проходим осмотры, лечимся, но, к сожалению, время познания себя упущено, организм приобрёл серьёзные сбои в работе систем органов. Нарушен обмен веществ, нарушен энергообмен...

Личность врача - это очень большой фактор в борьбе за здоровье пациента. А всегда ли у него есть силы, желание отнестись к данному пациенту серьёзно, есть ли время, наконец... умение? Умение переключаться с жалоб одного пагиента к жалобам друтого, проникновенно анализировать и сопоставлять те симптомы, которые вы назвали, и то, что видит он сам? Да, иногда всё же везёт с врачом, а врачу попадается толковый пациент. Можно смириться и с тем, что врач не навредил. Но иногда мы решительно протестуем, доказыпаем и не верим врачу - и это создаёт серьёзные препятствия к излечению.

Есть кожечно люди не согласные с такой постановкой вопроса. Они ипут пути и подходят к своему здоровью совершенно по-другому. Уметь самому прислушаться к своему организму, понять его и пробовать управлять своим состоянием как физическим так и духовнотм.

В Су-Джок терапии очень большое внимание уделяется мысли. Единство мысли врача и пациента, направленньгх на излечение. Очень важны внимание, вдумчивость. Эти простые на взгляд вещи очень необходимы как в нетрадиционной, так в традиционной медицине. Мысль материальна, но её единица бесконечно мала и ощутима лишь на ментальном уровне, также как и атом или клеточка $c$ её информационной системой лвляются единицами на физическом уровне.

Человек, как явление жизни - это маленькая Вселенная, неразрывно связанная с окружаюшим миром. Живое и неживое не существует само по себе, а вступает со Вселенной в неизбежные причинные отнотения. В физическом строении человека содержится вся информация, воспринятая из реалий Вселенной. И в этом заключается определённое таинство Подобия, так как согласно принципу голограммы маленькая частица несёт в себе всю информацию о целом. И человеку присуп дух целого, уменьшенный по форме. Например, так же как энергии ветра, тепла, жары, влажности, сухости, холода существуют во Вселенной - эти энергии существуют в человеческом теле, поддерживая жизнь. Гармоничное функционкрование в человеческом теле обеспечнвается за счёт теории Восьми начал, которая обеспечивает все стабильно существующие живые и неживые системы в мире (о теории Восьми начал будет 
интересно поговорить отдельно). Одним из началт для системы «человек» является мысль.

Изучение и лечение методом Су-Джок терапии приводит к физической и духовной гармонии. Клинические результаты Су-Джок терапии и её научные принципы дают базу, которая могла бы внести большой вклад в построение здорового обптества в нашем мире. Являясь экологически чистым методом оздоровления и лечения организма, Су-Джок терапия в настоящее время относится $к$ наилучпим существующим, а также постоянно развивающимся методам самопомощи. Это уникальное открытие XX-го века, автором которого является всемирно-известный учёный из Южной Кореи (Сеул) - неутомимый исследователь Пак Чже Ву. Без ножа и боли, без труднодоступныт и дорогостоящих фармакологияеских препаратов позволяет проводить диагностику и лечение больныг на физидеском и метафизическом уровнях, возвращая человеку здоровье тела и здоровье души. Профессор на своих лекциях призывает: «Начинайте сегодня же, не откладывайте, лечите себя, своих близких, соседей по мере освоения Су-Джок». Это напутствие имеет огромное практическое значение. Нужно и можно научить каждого человека лечиться самому, прислушиваться к своему организму и быть здоровым.

При первом же знакомстве с методами Су-Джок терапии становится ясно, насколько они логичны, просты и в применении безвредны. Природа подстраховала здоровье человека, дав ему возможность использовать бесконечно-больпое количество уровней и приёмов для излечения. Так можно ладонь или стопу представить как весь организм; можно представить весь организм лишь в одном люобом пальце, но так же можно найти все точки соответствия всему организму лишь на дистальной фаланге любого пальца. Возможности лечения увеличивағотся за счёт широкого использования существующего в организме и окружающем мире принципа подобия. Вглддимся в ступню - она так похожа по форме на почку! Две ступни, сложенныте вместе так же образуют одну почку, но разведя стопы, мы имеем доступ внутрь почки... Так же две сложенные ладони подобны сердцу с его главньми входящими и выходящими сосудами. И так далее.

Всё это открывает широкое поле в поиске подхода к лечению. А если учесть, что можно ещё лецить и более сложньми путями - через меридианы и чакры, становится ясным, насколько универсален метод Су-Джок. Наш маленький опыт (с 1995 года) уже подтверждает эффективность и доступность этого удивительного метода, которьй изложен в изданньтх томах профессора. Тот же, кто слушал и учился у самого Пака, считает себя рождённым вновь и смотрит на окружающий его мир другими глазами. Великая любовь к лодям заложена в методе Су-Джок, он доступен всем: богатьм и бедньтм.

Ещё в 1993 году Мейбл Арни, профессор из Бомбея, организовала у себя презентацию метода для учителей и директоров пкол, после чего 200 работников образования прошли курсы в педагогическом институте и припли к единому выводу: необходимо давать такие знания в школах! Только тогда они донесут великую любовь природы к людям, так как знания будут давать одинаково богатьм и бедным. Эти знания только в школах могут заставить убедить ребёнка быть ответственньм за своё здоровье, и что Су-Джок даёт такую возможность, т.к. действует лучше чем «скорая помощь». Дети убедятся, что природа сама вложила в наши тела лечебные системы, которые мы должны сами использовать в любом случае и в любое время.

Су-Джок терапия идеальна для преподавания в школах, любых массовых учебных заведениях, институтах и университетах - шариковая ручка, семена, пальцы, ногти могут быть использованы как для обнаружения, так и для лечения точек, соответствующих нездоровьп частям тела. 
И особенно вузы, которые готовят экологов, должны быть зачиншиками в убеждении консервативных представигелей на всех этапах системы образования в необходимости ввода предмета экологии и оздоровления организма с самого начала общеобразовательной школы! Только на этом этапе можно выработать привычку потребности быть здоровьд, а также просто научить уметь это делать.

Наш опыт занятий с детьми также показал положительные результаты: Су-Джок как игра, к ней тянутся дошкольники и ппкольники всех возрастов, с интересом смотрят на кисти и стопы, сами находят соответствия и подобия. Положительныте результаты лечения вселяют в них уверенность, а также дают им почувствовать причастность к чему-то серьёзному, необходимому и больпому: здоровью.

В своём небольтом докладе я пыталась показать фундаментальность этой науки, необходимой в нашем мире постоянных войн и противоречий, но мъ, экологи, должны с оптимизмом глядеть вперёд и нести вновь открытье знанъя и науку в массы.

Изучайте Су-Джок, и вы всё поймёте! Это даёт возможсность приблизиться к физической и духовной гармонии!

\title{
JUTEPATYPA
}

\section{ЛЕКЦИИ ПРОФЕССОРА ПАК ЧЖЕ ВУ}

издательство Су-Джок Академик, Москва, 1994-1998 гг. РУКОВОДСТВО ПО СУ-ДЖОК АКУПУНКТУРЕ. Пак Чже Ву. издательство Институга Су-Джок Акупунктуры, Корея, 1989 г.

\section{Основание:}

Международные сертификаты Ассоциации Су-Джок Акупунктуры, выданный на имя М. Смирновой в мае 1995 года за № 1130595 и в мае 1998 года за № 071-0598.

\section{ENVIRONMENTAL PROTECTION IN THE PROJECT „BALANCED DEVELOPMENT IN THE SPREE-NEISSE-BOBER EUROREGION"}

\author{
SZUSZKIEWICZ EWA (1), NAJBAR BARTEOMIEJ (2) \\ Technical University of Zielona Góra, Podgórna 50, 65-246 Zielona Góra \\ (1) Institute of Organisation and Management, (2) Institute of Sanitary Engineering \\ T.: (0045) 683254831, F.: (0048) 683245597
}

ABSTRACT. The Spree-Neisse-Bober Euroregion was established on the Polish and German borderland on September 21, 1993. The statutes, principles of co-operation, aims and tasks were elaborated. In the last seven years a number of investment projects have been carried out: the construction of a sewage treatment plant Gubin-Guben, a number of crossborder projects (founding the Landscape Park Krzesin-Neuzelle, sanctuaries of Nature, ecological grounds). One of the goals of the Spree-Neisse-Bober Euroregion" is to level the existing economic differences between Poland and Germany and to co-operate in the fields of culture, tourism, sports, education and mass media.

Key words: the Spree-Nysa-Bober Euroregion, Association of the Polish Communes, European Union, balanced development, environmental protection. 